\title{
Plea Bargain In White-Collar Crimes: An Argumentative Analysis
}

\author{
Sonia Ambreen Syed \\ School of Law \\ University of Karachi
}

\begin{abstract}
Plea bargain is a widely practiced and common characteristic in various international legal systems. However, in Pakistan it is rebuked for providing a legitimate outlet to white-collar offenders so they are not only able to clear their names from National Accountability Bureau's (NAB) investigation, but are also absolved from heavy financial penalization by submitting a meagre amount from their fraudulently acquired wealth. This article aims to study the theory of plea bargain and its origin, based on the theoretical research method of study. A critical analysis of the societal and constitutional implications of article 25 of National Accountability Bureau Ordinance (NAO), 1999 Pakistan, is also done. Coherent arguments are given in favour of retaining the provision of plea bargain while proposing specific guidelines to enhance the transparency of this process.
\end{abstract}

Keywords: Plea Bargain, NAB, White-Collar Crime, Financial Crime, Fundamental Rights, Prosecutorial Discretion, Corruption.

$$
\begin{aligned}
& \text { تلخيص }
\end{aligned}
$$

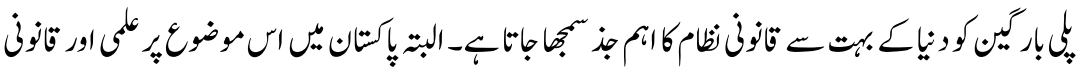

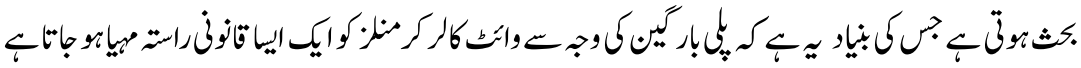

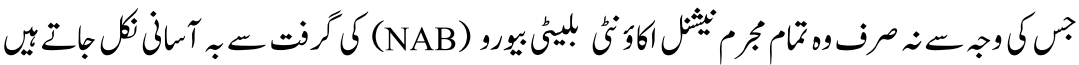

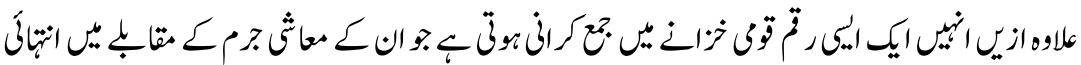

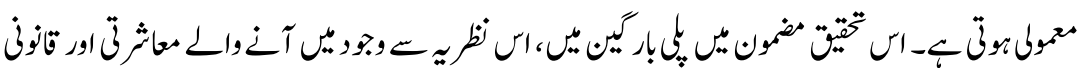

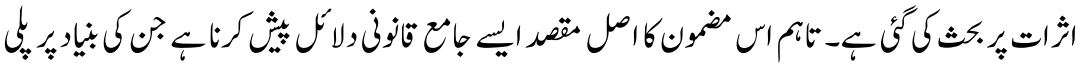

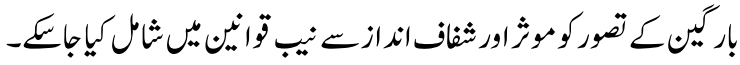

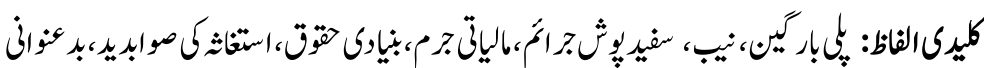

\section{Introduction}

This article intends to establish a coherent jurisprudential debate in support of the statutory option of plea bargain available to the financial/ white collar criminal 
given as clause $25 \mathrm{NAO}$. Additionally, the article will examine the legal intricacies and controversies regarding the moral implications as well as the legislative philosophy and efficacy connected with plea bargain.

During the time this article is written, the Government of Pakistan is working to amend the NAB statute in its entirety and introduce comprehensive guidelines for the betterment of the said section in order to ensure justice and transparency in the recovery of money. These legislative amendments are taking place when Pakistan is at the juncture of economic insolvency and the hope of prosperity in future. The State has decided to recover money from white-collar offenders who have used their social stature, political power and public-office position to commit fraud, corruption or money-laundering. In this regard, the role of the National Accountability Bureau (NAB) has taken the centre stage, as major recoveries are being done via NAB. Similarly, the article of plea bargain in NAB Ordinance, 1999 (NAO) is also being widely discussed for its lack of transparency and legislative ambiguities. As stated above, this article will argue in favour of retaining the provision of plea bargain; nevertheless, it is also acknowledged that there is an urgent need to improve the mode of operation with respect to the implementation of this section, as well as to make the role of NAB credible, just and transparent. Therefore, a comprehensive argument is made through this research to enhance the legislative procedure of plea bargain for white-collar crimes. Selective portions of section 25 (NAB, 1999), are reproduced herein below for the reference of the reader:

"where a government officer.... willingly confesses and agrees to return the gains obtained by him, the NAB Chairman has the power to accept the proposed amount ...the Chairman while using his discretionary authority accept the offer given by the accused on terms as he deems appropriate" (NAB, 1999).

In cases of civil nature plea bargaining (also referred to as 'negotiated settlements' or 'plea agreements') is described as concerting of an agreement where each party, involved in the plea bargain agrees to waive some legal entitlements, which they may have, if the case went either to the court for regular hearing or it was presented for an administrative hearing, and in both procedures the matter ends with a formal judgement. Moreover, during the procedure of plea bargaining the government body/agency would have to surrender certain rights for imposing enhanced penalizations, similarly the defendant also relinquishes certain legal safeguards which a formal trial would provide. In some cases, plea bargain also implies the waiver of any possibility from being exonerated and both parties consent to some form of a deal (OECD, 2008).

In criminal law plea bargain is defined as a formal settlement that takes place between the defendant and the public prosecutor, wherein the former pleads guilty 
to either a reduced charge or when indicted for several charges, the accused cop a plea to one or more charges, and in some cases even resulting in complete dismissal of charges. Negotiations involved in "implicit plea bargains" provide no guarantee of leniency. While the negotiations which result in normal or customary agreements are termed "explicit plea bargains".

Archival traces of plea bargain became evident around 1692 in the colonial era during a series of witchcraft cases, called the Salem Witch Trials. These cases were brought before the magistrates of the Massachusetts Bay Colony's settlement named Salem. In these trials the accused witches were given the option to either confess to committing witchcraft and remain alive or be executed if they refuted the allegations against them (Adams, 2009). The magistrates of Salem encouraged confessions as they wanted the witches who confessed to testify against other women accused of witchcraft (Burr, n.d.). Many of the accused women were saved from execution due to their confessions. Subsequently, it was the Salem Witch Trials which became the persuasive contention against the concept of 'plea bargain' since this procedure visibly indicated that every so often innocent individuals could be propelled to confess to the crime which they did not commit (Brooks, 2011).

Plea bargaining was strongly disapproved by the Appellate Courts during the Anglo-American time, rather it was generally met with strong disapproval on part of the (Alschuler, 1979). However, in the post-World War II years when the societal conflict in America was beginning to emerge as a result of rapid industrialization, urbanization and immigration, it affected the political institutions and made them spare and fragmented (Vogel, 1999). Amidst of significant criticism in the late $19^{\text {th }}$ century plea deals gained momentum, and the courts formally allowed plea bargaining to efficiently dispose of the cases, to promote political and economic stabilization(Meyer, 2017). Henceforth, the occasional leniency offered under common law was restructured as plea bargain (Encyclopedia, 2002).

Plea bargain consists of three main kinds: i) Charge-bargaining: the offender accepts the guilty plea for reduced charges, such as, being indicted for causing serious bodily injury rather than attempted murder; ii) Sentence-bargaining: in this deal the defendant receives guarantee of lesser / alternate sentencing in return of pleading guilty to the offence; iii) Count-bargaining: a defendant who is convicted for multiple charges is permitted to plead guilty to lesser offences. However, the offences committed are not necessarily analogous, and the State may reduce charges in return of a confession by the accused. It is an a periodic bargaining because it is used only in the cases of defendants who are charged with multiple offences. 
Plea bargaining refers to an agreement of defrayals and settlement of cases between corporations/individuals and the prosecuting authority for committing white-collar crimes like money laundering, scams, tax evasion, etc. (Russell, 2011). It comprises financial penalty and remedial measures, presented before the court for approval (Dervan, n.d.). In some cases it also involves making deferred prosecution agreements, through which companies are effectively put on probation, while also deferring full prosecution on the prerequisite that the stipulations stated in the agreement are met, thereby, preventing companies and /or individuals from convictions and allowing them to continue with their businesses, professions and occupational responsibilities (Graham, 2012).

\section{Research Questions, Objective and Scope}

1. How effectively has NAB adopted the principles of plea bargain, a concept which has its roots in the US criminal justice system?

2. Is Pakistan's current judicial system equipped with the appropriate regulatory framework that is able to ensure transparency and integrity in monetary recoveries from white collar offenders?

Resolving the cases of white collar crime has become an integral part of the criminal justice system in Pakistan. Notable fiduciary organs like the State Bank and Securities and Exchange Commission of Pakistan have suffered huge losses to national exchequer due to financial offences of businesspersons, public-office holders, public leaders, etc. Therefore, this article aims to propose efficacious regulatory/ legislative recommendations that could be incorporated in the NAB statute to bring transparency as well as productivity in the financial recovery procedure which significantly revolves around plea bargaining with the offenders.

This research article is primarily focused on the advancement and strengthening of the plea bargaining process adopted by NAB, although references have been made to cases of foreign jurisdictions yet the area of study is limited to Pakistan only.

\section{Review of Literature}

Plea deal is an acknowledged element of the U.S. legal system and has been used in Britain since 2015, it allow companies to circumvent criminal prosecution in a judicially permitted deal that often consists of fine and regulatory compliances. Nonetheless, in Pakistan, plea bargain is denunciated for being an escape route for the unscrupulous to 'clean' their misappropriated wealth by offering the State a trifling amount while retaining the major portion with themselves. The practice of plea bargain in Pakistan is censured not only for benefitting the elite white-collar offenders but also for absolving them from penalisation for their illegal gains (Dawn, 2018). 
Prima facie the provision of plea bargain in NAB Ordinance seems reasonable as it is cost-effective in utilizing the tax-payers' money and beneficial for the national exchequer, whereby, it receives the amount wrongfully acquired by a white-collar/financial offender. However, the drawback of this provision became apparent when NAB failed to receive any substantial amount in recovery from the offenders. If in a case NAB was able to make a plea bargain the money received was not only insignificant, but the investigation was always considered dubious and done for political victimization. Regrettably, this was the reality as well as a highly strong perception amongst the general public; nevertheless, in the years 2018-2019 NAB began to restore the trust of public as it conducted serious investigations of high-profile businesspersons, corporations, politicians, etc. and recovered Rs. 3349.736 million on account of plea bargain and voluntary returns and a further Rs. 21051.2 million by way of indirect recoveries with approximately 67 percent conviction rate in the courts (NAB, 2018).

Yet the legal problem and the moral dilemma of Plea Bargain is quite prevalent, highlighting the key lacunae of section 25: 1) the indiscriminate powers given to the NAB Chairman to unilaterally decide the recovery amount. 2) The Chairman is under no legal obligation to consult, inform the law ministry, trial court and/or high court while he is settling the plea deal with or discharging the offender from any liability and allegation. From NAB's viewpoint, plea bargain can result in efficient utilization of its time and financial resources and could also lead to improved implementation of its policies ultimately resulting in better crime prevention mechanism.

It has become a tradition to only publicly accuse or convict politicians for concealing their offshore income or illegally accumulated wealth, whereas companies, businesspersons, and public-office holders with far more greater financial crimes quietly enters into plea agreements with the NAB. Here, it is significant to mention that the Chairman NAB has unbridled powers to accept any monetary deal on behalf of the State from a white collar offender, and he has to merely inform the Court about the deal. Moreover, due to the abuse of political power, corruption, absence of judicial guidelines, lack of legislative or administrative control mechanisms regarding the modalities of plea bargain the elite offender gets superior treatment.

According to financial and legal experts plea bargains may have their utility, yet applying this method as the standard operating procedure in Pakistan, to recover the misappropriated money should be discouraged. Rather, our legislature is required to make concentrated efforts in restructuring the plea bargain process in cases of financial impropriety. In general, financial culpability must be fair and transparent, and everyone who is indicted for white collar crimes must be brought to justice, irrespective of their occupational respect or financial status. 
There are two contrasting ends to the broad spectrum of plea bargaining (Brown \& Bunnell, 2006) its opponents argue that it frustrates the process of justice by infringing the due process of civil, administrative and the criminal justice system, whereas, its exponents argue that it results in swift court proceedings along with a guaranteed conviction. The debate is advanced in the following sections, by primarily discussing the criticism against plea bargain followed by the supportive view of its proponents.

Many legal scholars argue that plea bargaining permits white collar criminals to escape appropriate punishment for their crimes; it unjustifiably pressurizes gullible defendants to agree to plea agreements due to their unawareness regarding the justice system; and at times it castigates those corporations or individuals who exercise their constitutional right to opt for trial (Bibas, 2004).

The major flaw in plea bargaining is excessive discretion granted to NAB Chairman in comparison to the judges, who are required to adhere to precise sentencing standards. According to one study, prosecutors have applied various methods of coercion and threatened the defendants to consent to plea settlements just to get a conviction, even though the evidence against them was insufficient. Moreover, several researchers have observed that as a result of wide latitude given to the competent authority, prosecutorial preferences influence the plea bargaining process. Additionally, several other studies have found that offenders who consent to plea bargaining can also receive lighter sentences due to the prosecutorial discretion; whereas the offenders who choose to be tried in the courts tend to receive severe punishments.

Various international research studies have expounded that factors such as race /caste, socioeconomic status, gender and age of defendants significantly contributes in accentuating the extrajudicial nature of plea bargain. Hence, studies also indicate that the extrajudicial characteristics of plea bargaining puts an offender belonging to ethnic minority in a vulnerable position as he/she might not be able to receive a just and reasonable plea settlement from the prosecuting authority. It has been found through strong evidence that the legal and extrajudicial nature of plea bargaining may significantly influence the legal proceedings depending on the region where the case is being investigated/ heard along with the prosecutorial discretion that is exercised.

Chances of exploitation increase immensely when unilateral powers are exercised by prosecuting authorities, as innocent individuals could be incriminated and coerced to pay money. Therefore, to avoid flagrant violations of human rights, it is mandatory to have a definite mechanism of judicial control.

Unfortunately, the unbridled powers of law enforcement agencies in Pakistan have the ability to threaten defendants with agglomerated charges against them if 
they fail to give consent to or cooperate in giving the plea bargained amount, thereby effectively creating a 'threatening' atmosphere. Plea bargains can also be coercive when legal safeguards are bypassed, for instance encouraging the accused to make a deal when she/he has no access to legal advice, or there is absence of an attorney who can inform them of their rights or not to divulge any of the evidence against them (PACE, 2019).

\section{Research Methodology}

For this article researcher has adopted doctrinal method of research, since the material analysed herein was specifically based on the principles of law, statutes, information collected from various legal-research articles and judgements of higher courts in Pakistan.

The legislative justification for incorporating the provision of plea bargain is for expediting criminal justice so authorities can avoid expensive and long trials, and succeed in recovering financially misappropriated amount. Contrariwise, due to plea-bargain many of the accused individuals are either taken into custody or in judicial remand, and compelled to give some amount of misappropriated/looted money- although the case against them is quite weak that it could have been dismissed due to lack of evidence.

\section{Results \& Findings Based on Policy Justifications in Plea Bargain for White Collar Crimes}

This indicates that NAB investigators and prosecutors are held to lower standards of investigation- and there is always a risk for individuals who enter the investigative process of NAB that they could be forced to take plea bargain or face the potential 'criminal case as well as public denigration,' whether they actually perpetrated or not. Furthermore, plea bargain creates a two-layered criminal justice system in Pakistan, where on one hand the privileged class offenders can easily afford expensive lawyers giving them advantageous position to avoid punishments, while, on the other hand, sole proprietors, small and medium business owners who do not have access to high-profile lawyers can be unreasonably proscribed.

Additionally, an indictment of a wealthy and powerful money launderer or tax evader, or an offender of varying financial crimes could quietly settle, within the office parameters of the NAB chairman, for a much less amount than what he had acquired through illegitimate means. The public would never be able to know the identity of the white-collar criminal who could have been a prominent businessman, politician, holder of a public office, a doctor or even a lawyer. This kind of secrecy during plea bargaining violates the right of every citizen to have 
access to information which could directly infringe their constitutional right to information thus affecting their lives and economic condition of their country.

Although from several supporting studies we could infer that both the prosecutorial discretion and the extrajudicial nature of plea bargain are able to affect adversely the indictment process for the white collar criminal ("Harvard Law and Economics Discussion Paper ", 2006), completely scrapping of the provision of plea bargain could over-burden court work. In this regard, various scholars and policymakers have expounded that there is a need to reform the process by limiting the prosecutorial discretion and introducing structured policy and legislative measures that will require firm guidelines when opting for plea bargain in financial or economic crimes (Bowers, 2008), thereby, mandating that both the judiciary and the prosecuting authority in-charge of the plea bargaining process practice substantial balance of power for all the parties involved (Lee, 2005). Therefore, it is imperative to mention that plea bargaining should be dealt with objectively so that the disparities within the system could be addressed effectively (Bowen, 2009).

Edward W. Sutherland coined the term white-collar crime in 1939 and also highlighted the multifarious aspects of this kind of financial crimes. Yet there were two main aspects of his research on the subject: 1) the socio-economic and professional status of the offender, 2) how easily the elite category of offenders can use their status in order to escape punishments and judicial/public reprimand. In order to deter the elite-offender from manipulating the process of justice it is imperative to strongly adhere to the concept and definition of white collar offences as given by Sutherland.

The actual outcome of punishment should be to restrain an individual from committing of injurious and wrongful acts (Sharma, 1998). The punishment meted out to a criminal should be an example for others and must serve as a warning that similar actions on their part would be dealt with similar punishment. Some schools of criminology believe in the exemplary theory of punishment according to which the punishment should be quick and harsh. The use of punishment is a means by which fear of crime can be aroused in people. It can be argued that true purpose of punishment is the welfare of society. Though the punishment is harsh, it serves as an example, excites fear of crime in general public, and thus really minimizes the occurrence of crime which in turn promotes the welfare of the society (Devers, 2011).

Keeping in view the above argument, it is significant that the name and full identity of the white collar offender who agrees on plea bargain should not be kept confidential. After the approval of the plea agreement from the court, charges laid and the amount received from the financial offender should be revealed to the 
general public by the financial authority. This measure not only satisfies the enquiry that was raised by Sutherland that a wealthy and respectful financial criminal influences the justice system, so his/her name is not shared with the general public and she/he could continue to live in the society as a respectful citizen of the country.

To support my argument, I would like to discuss the punishments announced by the District Attorney of Massachusetts, on March 2019. William Rick Singer was arrested for racketeering, conspiracy, obstruction of justice and money laundering conspiracy. Singer provided the services of college counselling and entrance-test preparation through his company called "Edge College \& Career Network LLC". Singer was also the CEO of an alleged charity named Key Worldwide Foundation (KWF). He was indicted for organizing nationwide bribery in SAT and ACT exams so the administrators would give permission to bogus candidates to secretly take college entrance exams in place of actual candidates. The exam administrators also corrected the answers for students after the test. Singe also bribed athletic coaches and administrators at the Yale University, Stanford and Georgetown University, UCLA, and University of Texas so they could facilitate the wrongful admission process of ineligible candidates to the elite universities as athletes. Singer used his charity KWF for money-laundering and concealing the sources of the bribes.

Approximately 33 parents paid substantial amount of money so their children would be able to have guaranteed admissions in some leading schools. The District Attorney stated that the parents who were involved in the fraud and bribery were the ideal examples of wealth and societal privilege and included the CEO's of companies, prominent real estate investors, well-known actresses, a well-known fashion designer and even chairman of an international law firm (Greenspan, 2019). The list of convicted professionals in the scam comprises athletic coaches of elite university, SAT/ACT exam administers, college administrator, exam proctor, educational coaches at Yale, Harvard, UCLA, etc. All the above-mentioned individuals were charged on several counts of white-collar crime, wherein, many consented to different kinds of plea bargains- ranging from lessening of severity of charges \& imprisonment time to paying monetary fine:

1. Charges on William Rick Singer: racketeering, money-laundering, deception of government and obstructing justice.

2. Charges on Rudolph Meredith (Aka Rudy) ex-coach of women's soccer team at the Yale University: honest services fraud and wire-fraud.

3. Charges on John Vandemoer ex-coach of sailing at the Stanford University: racketeering and conspiracy.

We can conclude from the above information that it's important to publicise identity of the white collar criminal along with complete details of the offence and 
how the sentence was settled through plea bargain so that apprehension of public humiliation could be provoked in society, which might to a certain extent, aid in creating deterrence (Benoliel, 2006). Some researchers of crime and penology believe that public humiliation and judicial-moral shaming of offenders is gaining recognition in the courts resulting in authentic demonstrations of remorse and apology from the defendants. Support for this argument can be found in Fritz Heider's developed models of attribution (Theory of Attribution), as well as in Social Exchange Theory that was created by George Homans in 1958 (Malle, 2011).

\section{Rationale for Plea Bargain}

From the above case we can further infer that plea bargaining can be costeffective for the tax-payers money as it provides an efficient mechanism for monetary recoveries. When the convicted individuals and companies accept the charges based on sound evidence through plea settlements, it effectively reduces the time of the courts to go through a detailed litigation and only a summary trial would dispose of the matter. Plea bargaining offers substantial advantage to the accused as well, by providing them the opportunity to be on-board in the disposition of their cases and produce more transparent and certain results.

However, plea bargaining can gain societal and legal acceptance only if NAB is able to successfully establish its reputation for being fair, consistent and always acting in good faith. In this regard, transparent and predictable procedural guidelines governing the plea settlements should be developed that would also permit certain flexibility on case-to-case basis (Wray \& Hur, 2006).

Plea bargain can also become highly productive if NAB establishes an authentic, updated public record of every monetary settlement it makes. So publishing plea bargains, reviewing guidelines on regular basis can contribute to achieve the desired goals. Similarly, fair and transparent bye-laws and detailed rules are to be drafted to monitor plea bargain (Taigue, 2007). It is imperative that defendants are given awareness of the rewards for cooperation along with the risks involved in case of failure to reach an agreement.

The stage when the court is involved in such cases, transparency of procedures and complete information about the offence and the aptness of a proposed fine/recovery-amount will add to the credibility of plea bargaining, while effectively alleviating any apprehensions regarding the after effects of plea deal on the fundamental rights of the offender.

To increase credibility in the process and lower the risk of an erroneous assessment of monetary compensation or recovery from the defendant, NAB 
should pursue to make deals with the offenders only in the cases where it has established all the relevant facts through unshakable evidence. So it is vital that the financial settlements should correctly estimate the loss to economy by a particular white collar offender as this can directly affect the overall deterrence impact. If conducted accurately the society at large could also benefit from plea bargains as they can play a vital role in productively utilizing limited resources and maximizing deterrence.

\section{Conclusions}

It is pertinent to highlight NAB's plea bargaining process before the recommendations are given. According to the plea bargain data available on NAB'S online database for the period of ( $1^{\text {st }}$ July 2016 to $3^{\text {rd }}$ March 2019)630 people entered into financial settlements with NAB(NAB Operations, 2019). Thereafter, it mentions three categories namely: Amount Alleged, Amount Determined,\& Amount Agreed with every accused. However, what NAB fails to explain is how it has calculated the alleged amount of misappropriations and on what terms the payment of the said amount was agreed between the parties (Choudhry, 2019).

NAB since its inception has always been under severe public and media scrutiny and criticism("Increasingly controversial NAB", 2018). In numerous cases NAB authorities have been accused of harassing and blackmailing businesspersons and political rivals of the ruling parties (Iqbal, 2015). Although NAB has been able to recover more than Rs. 300 billion over the period yet the covert and unilateral nature of plea bargain decisions taken by NAB Chairman were always shrouded with controversies. It is the most appropriate time to ensure the trust of public in NAB is safeguarded (Khan, 2019).

Therefore, in order to retain public's confidence in NAB the process of plea bargaining should be revamped- as it could prove to be a vital instrument for recovering misappropriated money provided if appropriate safeguards are in place (Sahi, 2019). Furthermore, plea bargain could also result in more efficient criminal justice system for white-collar crimes (Attorney General, n.d.). The following recommendations give a framework for further legislation of guidelines and regulations:

1. NAB should act fairly, unambiguously, and in the interests of justice while making the decisions for plea-bargaining. NAB should fully ensure that the financial deal reflects the seriousness of the offence and that NAB will not consent to a lesser amount of plea bargain than which is due and correctly calculated. 
2. An independent body within NAB is required to be created, which will decide the terms of plea bargain individually, on case-to-case basis. No individual should be authorized to unilaterally decide any condition for settling the recovery amount or releasing the accused from NAB's reference or investigations.

3. Rules for the modus operandi will be made comprehensively and fairly valuing the legal rights of an individual/ company being investigated for white collar offenses.

4. To initiate the negotiations for plea bargaining NAB will send an official letter to the defendant's lawyer asking the defendant's lawyer to enter into negotiation for plea bargain.

5. NAB or any of its prosecutors will not coerce an accused person during the course of plea bargain; and while adhering to the best standards of transparency NAB should ensure that:

a. Comprehensive record of the entire negotiations of plea bargaining will be maintained;

b. Defendants will be given proper information with respect to their cases;

c. Every term of the plea bargain between NAB and a defendant will be written in a Plea Agreement, and any deal/agreement before becoming effective will be presented in the court providing an accurate description of the terms and conditions agreed upon;

d. Prosecuting authority is not permitted to settle with a defendant on any additional matters that are not mentioned in the agreement of plea settlements presented before the court.

6. Finalized and signed plea agreement will be treated as the evidence of confession.

7. Finalized written plea agreement shall be signed by both parties before its presentation to the court and shall consist of: 1) complete statement of the facts and charge, 2) a signed declaration by the defendant whereby he/she accepts the stated facts and concedes to his /her guilt on the agreed charges;

8. NAB will provide the court sufficient material (including any correspondence and minutes of any meetings held between the parties) so the judge is able to assess the fairness of the plea bargain;

9. Once the plea deal is presented in the court, it would be the court's prerogative to approve or reject the plea bargain agreement;

10. Categories of updated white-collar crime, base count (that is severity of the crime), sentencing-guidelines and fast track system of prosecution for financial/economic crime cases will be introduced by NAB.

11. Any information provided by the defendant or his lawyer will only be disclosed to another party if it is required by law and will be treated with confidentiality; 
12. Legal representative of the defendant will be required to give a signed affidavit in to that the information shared by the prosecutor during plea discussions shall remain confidential. Unless the matter of 'confidentiality' is satisfactorily agreed between the parties in the form of signed undertakings, the prosecuting authority will not continue with the plea bargain negotiations (Thompson, 2002).

13. NAB will make available to the public complete and updated statistics of every white-collar crime it enquires, investigates, file references for and make deals of plea bargain.

\section{References}

Adams, G. (2009). The Specter of Salem: Remembering the Witch Trials in Nineteenth-Century America. University of Chicago Press.

Alschuler, A. W. (1979). Plea Bargaining and Its History. Law \& Society Review, vol.13, pp.211-245. Retrieved from https://www.jstor.org/stable/3053250

Annual Report (2018). Islamabad: NAB. Retrieved from https://www.thenews.com.pk/print/464862-nab-chairman-presents-annualreport-to-president

Attorney General's guidance to the legal profession (n.d.). Retrieved from https://www.gov.uk/guidance/plea-discussions-in-cases-of-serious-orcomplex-fraud--8\#b-general-principles

Benoliel, B. (2006). Public Humiliation as a Mitigator in Criminal Sentencing (dissertation). Walden University Scholar Works. Retrieved from file://C:/Users/SonyaSyed/Downloads/Documents/72d4436d44e6e3eefc9 f893ceb062e10ae33.pdf

Bibas, S. (2004). Plea Bargaining Outside the Shadow of Trial. Faculty Scholarship at Penn Law. Retrieved from https://scholarship.law.upenn.edu/ faculty_scholarship/924

Bowen, D. M. (2009). Calling Your Bluff: How Prosecutors and Defense Attorneys Adapt Plea Bargaining Strategies to Increased Formalization. Justice Quarterly, 26. Retrieved from https://ssrn.com/abstract=1128409

Bowers, J. (2008). Punishing the Innocent. In PENN LAW REVIEW (5th ed., Vol. 156, p. 1117). Pennsylvania: University of Pennsylvania Law Review. Retrieved from https://scholarship.law.upenn.edu/penn_law_review/ vol156/iss5/1/ 
Brooks, R. B. (2011). History of the Salem Witch Trials. Massachusetts: History of Massachusetts Blog. Retrieved from https://historyofmassachusetts.org/ the-salem-witch-trials/

Brown, M. P. \& Bunnell, S. E. (2006). Negotiating Justice: Prosecutorial Perspectives on Federal Plea Bargaining in the District of Columbia. American Criminal Law Review, vol.43:3, pp.1063-1094.

Burr, G. L. (n.d.). Narratives of the Witchcraft Cases, 1648-1706. New York: C. Scribner's Sons.

Choudhry, F. (2019, March 30). Inconsistent Accountability. International The News. Retrieved from https://www.thenews.com.pk/print/450729inconsistent-accountability

Dervan, L. E. (n.d.). Plea Bargaining's Survival: Financial Crimes Plea Bargaining, a Continued Triumph in a Post-Enron World.

Devers, L. Plea and Charge Bargaining- Research Summary (2011). Retrieved from https://bja.ojp.gov/sites/g/files/xyckuh186/files/media/document/PleaBarg ainingResearchSummary.pdf

Graham, K. (2012). Crimes, Widgets, and Plea Bargaining: An Analysis of Charge Content, Pleas, and Trials. California Law Review, vol.100:06, pp.630-1573. Retrieved from http://www.jstor.org/stable/23409481

Greenspan, R. E. (2019, August 22). Lori Loughlin and Felicity Huffman's College Admissions Scandal Remains Ongoing. Here Are the Latest Developments. Time. https://fp.brecorder.com/2018/10/20181026418814/

Increasingly controversial NAB. (2018, October 26). Business Recorder. Retrieved from https://fp.brecorder.com/2018/10/20181026418814/

Iqbal, N. (2015, February 19). NAB affairs come under scrutiny at Supreme Court. $D A W N$. Retrieved from https://www.dawn.com/news/1164534/nabaffairs-come-under-scrutiny-at-supreme-court

Khan, S. (2019, April 18). Plea bargain concept exists in Pakistan only: SC. Retrieved from https://www.thenews.com.pk/print/459856-plea-bargainconcept-exists-in-pakistan-only-sc 
Korman, Joanna. (2013). Malle, B. F., \& Korman, J. (2013). Attribution theory. In D. S. Dunn (Ed.), Oxford Bibliographies in Psychology. New York: Oxford University Press.

Lee, S.H. (2005). The Scales of Justice: Balancing Neutrality and Efficiency in Plea-Bargaining Encounters. Discourse and Society, vol.16:1, pp.35-54.

Lucian e. Dervan, Plea Bargaining's Survival: Financial Crimes Plea Bargaining, a Continued Triumph in a Post-Enron World, 60 Okla. L. Rev. 451 (2007),https://digitalcommons.law.ou.edu/olr/vol60/iss3/1

Meyer, J. (2017, August 30). Plea bargaining. In Encyclopcedia Britannica, inc. Retrieved from https://www.britannica.com/topic/plea-bargaining

NAB Ordinance (1999). Retrieved from http://nab.gov.pk/Downloads/nao.asp

NAB. Voluntary Return / Plea Bargain Data, (n.d.). Karachi, Sindh. Retrieved from http://nab.gov.pk/nab_ops.asp

O. E. C. D. P. R. (2008). Plea Bargaining/Settlement of Cartel Cases. Plea Bargaining/Settlement of Cartel Cases. Organisation for Economic Cooperation and Development, Directorate for Financial And Enterprise Affairs Competition Committee

O., B.-G., \& G.-A. (2006). Plea Bargains Only for the Guilty. In Harvard Law and Economics Discussion Paper, Journal of Law \& Economics, vol.481, pp.353-364.

PACE (2019). PACE Adopts Draft Resolution Recognising the Threats Plea Bargaining Poses to Human Rights. Retrieved from https://www.fairtrials.org/news/pace-adopts-draft-resolution-recognisingthreats-plea-bargaining-poses-human-rights

Plea bargains. (2018, August 2). Dawn. Retrieved from https://www.dawn.com/news/1424398

Russell, J. (2011, December 4). Plea bargaining for financial crime set to come into law early next year. The Telegraph. Retrieved from https://www.telegraph.co.uk/finance/financial-crime/8934443/Pleabargaining-for-financial-crime-set-to-come-into-law-early-next-year.html 
Sahi, N. (2019, September 5). NAB chief okays Rs10.6b plea-bargain. The Nation. Retrieved from https://nation.com.pk/05-Sep-2019/nab-chiefokays-rs10-6b-plea-bargain

Sharma, R. K. (1998). Criminology and Penology. New Delhi: Atlanta Publishers and Distributors.

Taigue, L. E. (n.d.). Justice Department's Policy on Corporate Prosecutions under Attack: United States v. Stein Assails Thompson Memorandum. Retrieved from https://digitalcommons.law.villanova.edu/vlr/vol52/iss $2 / 6$

The Encyclopedia of Criminology and Criminal Justice (2014). Retrieved from https://onlinelibrary.wiley.com/doi/book/10.1002/9781118517383

Thompson Memorandum. Villanova Law Review, 52, 369. Retrieved from Thompson, L. D. (2002, October). Retrieved from http:/www.usdoj.gov/ archive/dag/speech/2002/102802daywithjustice.htm

Vogel, M. E. (1999). The Social Origins of Plea Bargaining: Conflict and the Law in the Process of State Formation, 1830-1860. Law \& Society Review, vol.33:1, pp.161-246.

Wray, C. A., \& Hur, R. K. (2006). Corporate Criminal Prosecution in a PostEnron World: The Thompson Memo in Theory and Practice. American Criminal Law Review, 43:3, pp.1095-1188.

Sonia Ambreen Syed is an Assistant Professor in the School of Law, University of Karachi, Karachi, Pakistan. 